\title{
Ineffectiveness of Online Interactive Video Content Developed for Programming Education ${ }^{1}$
}

\author{
Mahmut Can SÖZERi ${ }^{1}$ \\ Serhat Bahadır KERT ${ }^{2}$ \\ ${ }^{1}$ Kuveyt Turk Participation Bank IT R\&D Center \\ ${ }^{2}$ Y 1 ldız Technical University
}

DOI:10.21585/ijcses.v4i3.99

\begin{abstract}
In this study, the effects of interactive video usage in programming education on academic achievement and self-efficacy perception of programming were investigated by taking into account learning styles. The research was patterned according to the causal-comparative model, and also, correlation analysis was performed for related research. Sixty-one students attending 3rd grade in Computer and Instructional Technology Education (CEIT) of Yildı Technical University participated in the study. Research data were collected with "Interview form," "Academic Achievement Test," "self-efficacy scale for programming," "learning styles index" and "interactive Video system." ANCOVA, Correlation and Kruskal Wallis H-test were used in the analysis of the data. The data was analyzed on the computer with the SPSS package program. According to research findings, interactive video monitoring rates did not differ significantly in the students ' academic achievement and self-efficacy perceptions of programming. It was found that students ' learning style preferences had no impact on interactive video viewing rates. The relationship between the change in students ' academic achievement and the change in self-efficacy perception scores related to programming has been examined; as academic achievement increases, it has been concluded that the perception of self-efficacy about programming has fallen.
\end{abstract}

Keywords: Interactive video; computer science education; learning style; programming; self-efficacy of programming.

\section{Introduction}

With the technology that develops day by day, internet tools have been affected by these developments and have brought up a new concept with them.: Web 2.0 (Akar, 2010). Different researchers offer various definitions of Web 2.0. For example; Tu, Blocher, and Ntoruru (2008) define it as "a Web technology that aims to enhance creativity, information sharing and collaboration among users" (p. 336). Scrum and Levin (2009) emphasize the same features and explain it as the second generation of the internet that supports creativity, information sharing and collaboration. Akar (2010) states that Web 2.0 is a technology that makes the internet more participatory, creative and social. Bustamante (2017), prefers to use the term as one of the key mediums of technology-based teaching and defines it as effective interactive media used to improve students' achievement in the classroom. . Web 2.0 is emerging development to increase the usability and functionality of web technologies (Karaman, Yıldırım \& Kaban, 2008). In this research, with the perspective of interaction, Web 2.0

1 This article was produced from master thesis of Mahmut Can SÖZERİ 
is operationally defined as the technology improving interactivity among all stakeholders of the internet. Some of the Web 2.0 tools can be listed as follows: Social networking systems-Twitter, Facebook, video sharing sites-YouTube, Google video, image sharing sites-Flickr, Instagram, wikis, blogs, virtual worlds, podcasts, interactive video systems (Munoz and Towner, 2009; Brame, 2016). Videos are one of the Web 2.0 technologies, which is becoming very popular and also used frequently (Kolowich, 2016). Additionally, it can be said that there has been an increase in video usage rates in educational contexts (Yıldırım \& Özmen, 2012). Improving learner motivation is one of the important reasons for using video content in educational environments. Videos increase the motivation of tech students if used as learning and teaching tools (Duffy, 2008). However, if the non-interactive video was used during the teaching process, an insufficient level of satisfaction was revealed (Kozma, 1986). The reason for this is that video surveillance provides a passive experience as in reading (Brame, 2016). Interactive video (Schaffer \& Hannafin, 1986), also known as hyper video (Petan, Petan \&Vasiu, 2014), is an instructional technology that combines the computer's ability and capabilities of video, allowing the student to interact with an instructional video from a passive audience position (Zhang, Zhou, Briggs \& Nunamaker Jr., 2006). Some of the ways to make a video interactive video are;

- Embedding open-ended and multiple-choice questions on video and giving feedback based on responses (Schaffer \& Hannafin, 1986; Yin, Lin, Yang and Chen, 2013),

- Repeating of the specific section on the video according to the answers given to the questions and continuing to this repetition until the correct answer is answered (Schaffer \& Hannafin, 1986),

- Displaying chapter titles on video, including sections of topics within the video (Petan, Petan \& Vasiu, 2014),

- Showing and drawing text, tables, and images on the video. (Yin, Lin, Yang and Chen, 2013)

Interactive video usage increases attention, remembering, satisfaction and video viewing times (Clothier, 2013). In this context, in academic studies (Barthel, Ainsworth \& Sharsples, 2013; Hrastinski \& Monstad, 2014; Yin, Lin, Yang \& Chen, 2013) it has been observed that video-based systems including technological futures to support user-computer interactions.

In this study, interactive videos were used in the process of graphics-based programming language education. The interactive videos are based on "how-to" videos which are used to teach new skills or new techniques/technologies. It is seen that "how-to" videos are becoming more and more popular in video distribution environments. In the Twenty-First Century, individuals are expected to make production on their own as well as consumption (Kalelioğlu, 2015). Interactive videos can help them to create new things on their own. The value given to the training of individuals who can produce on their own by learning programming is evident (Ersoy, Madran \& Gülbahar, 2011; Kukul and Gökçearslan, 2014). The value given to programming in Turkey is increasing day by day (Kert and Uğraş, 2009). Nowadays, various approaches are being used by practitioners to improve the programming skills of the students. This research has been focused on the effect of interactive videos on the success of the students in programming courses. Additionally, Self-efficacy and learning styles of the individuals have been thought of as two important factors affecting video-supported education and therefore added to the investigation of the correlations.

Self-efficacy for programming is one of these areas (Altun and Mazman, 2012). Programming skills are seen as more challenging to understand than university-level courses such as mathematics and science (Aşkar and Davenport, 2009). This is because individuals see programming as a more difficult issue to understand, in other words, their perceptions of self-efficacy about programming are low (Altun and Mazman, 2012). In the field of literature, several studies have been examined between academic achievement and self-efficacy, but it has been observed that there is an inadequate number of studies taking into account the impact of self-efficacy on programming skills (Aşkar and Davenport, 2009). Because of the different mental processes of the students in the research, it has been found that they have configured and identified information differently (Samanc1 \& Keskin, 2007). The self-efficacy of the individual can be seen as an essential factor in the development of programming skills. Self-efficacy is defined as "self-judgment about the capacity of the individual to organize and successfully perform activities necessary to show a certain performance" (Gözüm and Aksayan, 1999). This concept is used by adapting to different disciplines and fields (Seferoğlu \& Akbıyık, 2005).

Learning styles affect the structure of learning-teaching environments (Arslan and Aksu, 2006). Therefore, in educational settings, teachers need to have general knowledge about the profiles of learners (Arslan and Aksu, 2006; Felder and Henriques, 1995). There are many inventories developed to identify learning styles. One of 
them is the learning style index which was developed by Felder and Silverman in 1994 (Felder and Soloman, 1994). This index determines the learning style preference in 4 factors with 44 questions. Felder's learning factors are doing-thinking, feeling-intuitive, visual-verbal, sequential-holistic (Howard, Carver, and Lane, 1996). Before preparing the index of learning style factors and learning styles, Felder examined four learning model styles: The Myers-Briggs Type Indicator(MBTI), Kolb's Learning Style Model, The Herrman Brain Dominance Instrument (HBDI) (Thomas, etc., 2002).

The main aim of the research is to examine the effect of interactive course video support on the process during the programming education process. Given the possible effect of self-regulation skills and learning style of the students it is aimed to find the answers to the following sub-problems:

RQ1: Is there a significant correlation between interactive video monitoring rates and self-efficacy perception scores for programming?

RQ2: Is there any effect of learning styles on video monitoring rates of the students?

RQ3: Is there a significant correlation between students' academic achievement and interactive video viewing rates?

RQ:4 Is there a significant correlation between the change in students' academic achievement and the change in self-efficacy perception scores related to programming?

\section{The study}

List of Abbreviations

$\begin{array}{ll}\text { AAT } & \text { : Academic Achievement Test } \\ \text { CPSES } & : \text { Self-efficacy Scale For Programming } \\ \text { ILS } & : \text { Index of Learning Styles } \\ \text { IVMR } & : \text { Interactive video monitoring rates } \\ \text { IVS } & : \text { Interactive video system } \\ \text { G } & \text { : Study Group } \\ \text { ILS } & : \text { Index of Learning Styles }\end{array}$

\subsection{Method}

The study was designed according to the causal-comparative model, and the correlation research model was used in the research. A causal-comparative research pattern is a pattern used to determine the causes or consequences of differences between groups within existing groups (Fraenkel, Wallen\& Hyun, 2011). The correlation model is the model used to determine the relationship between variables (Sönmez \& Alacapınar, 2013). In the correlation model, a causal comparison model is needed because no interpretation can be made in the context of the cause-effect model. The causal-comparative research model is the study of "determining the causes that influence the results of a completed case." (Sönmez \& Alacapınar, 2013). In this model, the researcher does not insert any variables in the environment, nor does he interfere with the results. Therefore, this model is used to determine the differences between individuals. (Büyüköztürk, Çakmak, Akgün, Karadeniz \& Demirel, 2010).

The dependent variables of the research are the perception of self-efficacy in programming and academic achievement. The independent variables are the learning styles, the IVS (interactive video system) monitoring rates, and the number of questions they answer correctly in IVS. Scale and tests were applied to all students in the study group. At the same time, all students had the opportunity to use IVS. The symbolic representation of the study with these explanations is presented in Table 1:

Table 1. The Symbolic Representation Of The Research Model

\begin{tabular}{llll}
\hline Group & Pre-Test & Process & Post-Test \\
\hline G & AAT1 & Conventional Course & AAT2 \\
\hline
\end{tabular}




CPSES1 Use of IVS as a supportive source CPSES2

ILS

\subsection{Participants}

This research was carried out with 66 students in 2 groups who took Multimedia Design and production courses while studying in the computer and instructional technologies Education Department of Yildiz Technical University Faculty of Education. However, during the research process, six students who did not attend the courses regularly and who did not support the studies were excluded, and the study was completed with 60 students. All students who participated in the study were provided with access information for IVS, which was developed by the researcher, and they were allowed to use IVS.

In this study, groupings were made by causal-comparative research pattern: IVS never used/viewers (never viewed), IVS infrequent users/viewers (1.5 hours or fewer), IVS active users/viewers (1.6 hours and more). The reason for the preference of this course is that students have taken courses in the first grade, second grade, and the first semester of third grade, and have gained fundamental knowledge and skills on this subject. Besides, students who failed to take the course in previous years and who took the course from the upper grade even though they were in a lower grade are not included in the study. Nobody was forced to watch videos throughout the semester. Just, gift cards were used as motivators of the process. In the first week, It has been announced that 10 students with the highest video viewing rates will be rewarded with a gift card from a book store.

Students have taken three hours of Multimedia Design and Production courses per week. The course is given in the classroom environment and by CEIT faculty members. The videos on IVS were obtained weekly by using the Camtasia program at the end of the course, which was conducted by the researcher, and uploaded to IVS. The researcher and the lecturer of the course have provided the recording of the videos in a coordinated way, before and after each course, in the same way as the content of the course. After the videos were taken, the interaction was added and made available to students at IVS.

Table 2. Demographics of the Participants

\begin{tabular}{llllll}
\hline Age (Year) & f & \% & Gender & f & $\%$ \\
\hline $\mathbf{1 8 - 2 0}$ & 13 & 21.67 & Male & 29 & 48.33 \\
\hline $\mathbf{2 1 - 2 5}$ & 44 & 73.3 & Female & 31 & 51.67 \\
\hline $\mathbf{2 6 - 3 5}$ & 3 & 5 & Total & 60 & 100 \\
\hline Total & 60 & 100 & & & \\
\hline
\end{tabular}

The study included 60 students, 29 of them are males $(48.33 \%)$, and 31 of them are females $(51.67 \%)$. When students' ages were examined, the age distribution was found to be between 18-20 (21.67\%) and 21-25 (73.3\%). Also, 5\% of the students were found to be in the age group of 26 and above. Additionally, In Table 3, The results of the students according to the Felder and Soloman learning styles index are given. In the results, each student is presented in detail as weak-medium-strong according to four factors and two poles of each factor.

Table 3. Learning Styles of Students in 4 Factors

\begin{tabular}{llcc}
\hline Learning Style & Efficacy & f & $\%$ \\
\hline \multirow{2}{*}{ Doing-Thinking } & Doing - Weak & 31 & 50.82 \\
& Doing - Medium & 10 & 16.39 \\
& Doing - Strong & 4 & 6.56 \\
& Thinking - Weak & 13 & 21.31 \\
& Thinking - Medium & 3 & 4.92
\end{tabular}




\begin{tabular}{|c|c|c|c|}
\hline & Total & 61 & 100 \\
\hline \multirow{7}{*}{ Intuitive - Feeling } & Intuitive - Weak & 6 & 9.83 \\
\hline & Intuitive - Medium & 2 & 3.28 \\
\hline & Intuitive - Strong & 0 & 0 \\
\hline & Feeling - Weak & 32 & 52.46 \\
\hline & Feeling - Medium & 19 & 31.15 \\
\hline & Feeling - Strong & 2 & 3.28 \\
\hline & Total & 61 & 100 \\
\hline \multirow{7}{*}{ Visual - Auditory } & Visual - Weak & 21 & 34.42 \\
\hline & Visual-Medium & 19 & 31.15 \\
\hline & Visual - Weak & 15 & 24.60 \\
\hline & Auditory - Weak & 3 & 4.92 \\
\hline & Auditory - Medium & 2 & 3.28 \\
\hline & Auditory - Strong & 1 & 1.64 \\
\hline & Total & 61 & 100 \\
\hline \multirow{7}{*}{ Sequential - Holistic } & Holistic - Weak & 15 & 24.60 \\
\hline & Holistic-Medium & 3 & 4.91 \\
\hline & Holistic - Strong & 0 & 0 \\
\hline & Sequential - Weak & 28 & 45.90 \\
\hline & Sequential - Medium & 14 & 22.95 \\
\hline & Sequential - Strong & 1 & 1.64 \\
\hline & Total & 61 & 100 \\
\hline
\end{tabular}

As shown in Table 3, students' apparent distributions of learning styles are as follows: $50.82 \%$ Doing-Weak, $52.46 \%$ Feeling-Weak, $45.90 \%$ Sequential-Weak.

\subsection{The Data Collection Tools}

The data obtained in this study were collected through tests and scales, a. Pre-test, self-efficacy perception scale and learning styles index, which are achievement tests, were applied before the use of IVS. In the process of using IVS, information about using IVS has been collected. After the use of IVS, the self-efficacy scale for programming and final-test was applied.

The "Academic Achievement Test" was developed by the researcher to scale the success of the interactive video system for students in software education. To have a measurement tool validity, "all observed and measurable properties of the desired quality should be present in a measurement tool." (Sönmez and Alacapınar, 2013). The validity of the academic achievement test has been decided by taking expert opinion from the faculty member of the course. The Achievement Test has been prepared as 40 questions to measure target behaviors. The test was applied to 51 students in the study group. It is not possible to reach consistent and accurate judgment with the data obtained through reliable and non-valid measurement tools (Sönmez and Alacapınar, 2013). In this respect, the reliability of the test was determined by Kuder-Richardson-20 (KR-20) technique. As a result of the application, the KR-20 Reliability Coefficient was calculated as 0.59 . For each subject in the Achievement Test, difficulty and differentiation indices were calculated. There are 20 questions in the final of the Achievement Test after the removed substances. KR-20 Reliability Coefficient was calculated as 0.77 . The average degree of difficulty of the substances was found as 0.48 . The degree of difficulty of the substances in the test varies between 0.21 and 0.79 . 
The test includes four simple questions, nine moderate questions, and seven difficult questions.

To determine learning styles, we used the "Learning Style Index" developed by Felder and Silverman (1988) which is based on the learning style model and scaled by Felder and Soloman (1994) and adapted to the Turkish language by Samanc1 and Keskin (2007). The web-based version of the Felder-Soloman Learning Style Index has been used by more than 100,000 people each year to determine the learning style and has been involved in many studies (Litzinger, Lee, Wise \& Felder, 2005). The validity and reliability of the index were made by Samanc1 and Keskin (2007) and by Litzinger and colleagues (2005). Reliability Coefficients are shown in Table 4.

Table 4. Reliability Coefficients of Four Learning Styles in The Index

\begin{tabular}{llllll}
\hline $\begin{array}{l}\text { Doing } \\
\text { Thinking }\end{array}$ & $\begin{array}{l}\text { Feeling } \\
\text { Intuitive }\end{array}$ & $\begin{array}{l}\text { Visual } \\
\text { Auditory }\end{array}$ & $\begin{array}{l}\text { Sequential } \\
\text { Holistic }\end{array}$ & N & Study \\
\hline 0.43 & 0.54 & 0.59 & 0.32 & 381 & Samanc1 and Keskin (2007) \\
0.60 & 0.77 & 0.74 & 0.56 & 572 & Litzinger and colleagues (2005) \\
\hline
\end{tabular}

For all of the learning factors, Samanc1 and Keskin (2007) found that the correlation between factors was quite close to zero and statistically equal to zero. Litzinger and his colleagues (2005) also stated that each factor corresponds to all the objectives of the scale. Forty-four substances contained in this index are made up of four factors. These factors are Doing-Thinking, Feeling-Intuitive, Auditory-Visual, and Sequential-Holistic. Each factor is matched with 11 expressions. Each expression consists of two options: A and B. According to the number of A and B responses given for each factor, it defines the level of the respective factor to be strong, medium and weak (Samanc1 and Keskin, 2007).

In this study, the "Self-Efficacy Perception Scale For Programming" developed by Ramalingam and Wiedenbeck (1998) and adapted to Turkish by Altun and Mazman (2012) was used to determine the perception of self-efficacy in programming. The scale developed by Ramalingam and Wiedenbeck (1998) for C++ programming language is used in Java programming language, Aşkar and Davenport (2009). The scale, which was developed in English and consisted of 32 items, was determined by the research conducted by Altun and Mazman (2012), which consisted of 9 items and 2 factors in Turkish form.

\subsection{Interactive Video System (IVS) features}

IVS is the general name of the system that the learner uses continuously during a teaching process. The student on the IVS performs all transactions and all processes. The administrator/instructor/teacher communicates with this system through the management panel. The overall structure of the system is shown in Figure 1.

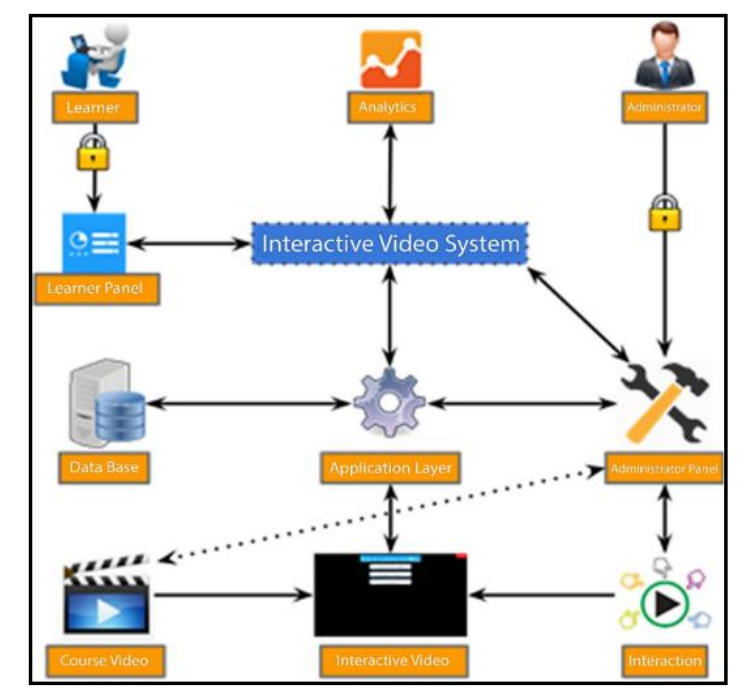

Figure 1. Interactive Video System (IVS) usage scheme 
Students entered the IVS system through the student login screen. It is also stated that the student number and password must be in a specific pattern and the warning should be given in case of an incorrect entry. The first screen of the student after logging in to IVS is the IVS Home Screen. This screen contains topics and sub-topics. The middle section shows the video about the sub-topic clicked. The video opens in the middle of the page to fit the screen resolution, clicking on one of the topics in the left menu. A view of the IVS video display page is shown in Figure 2 .

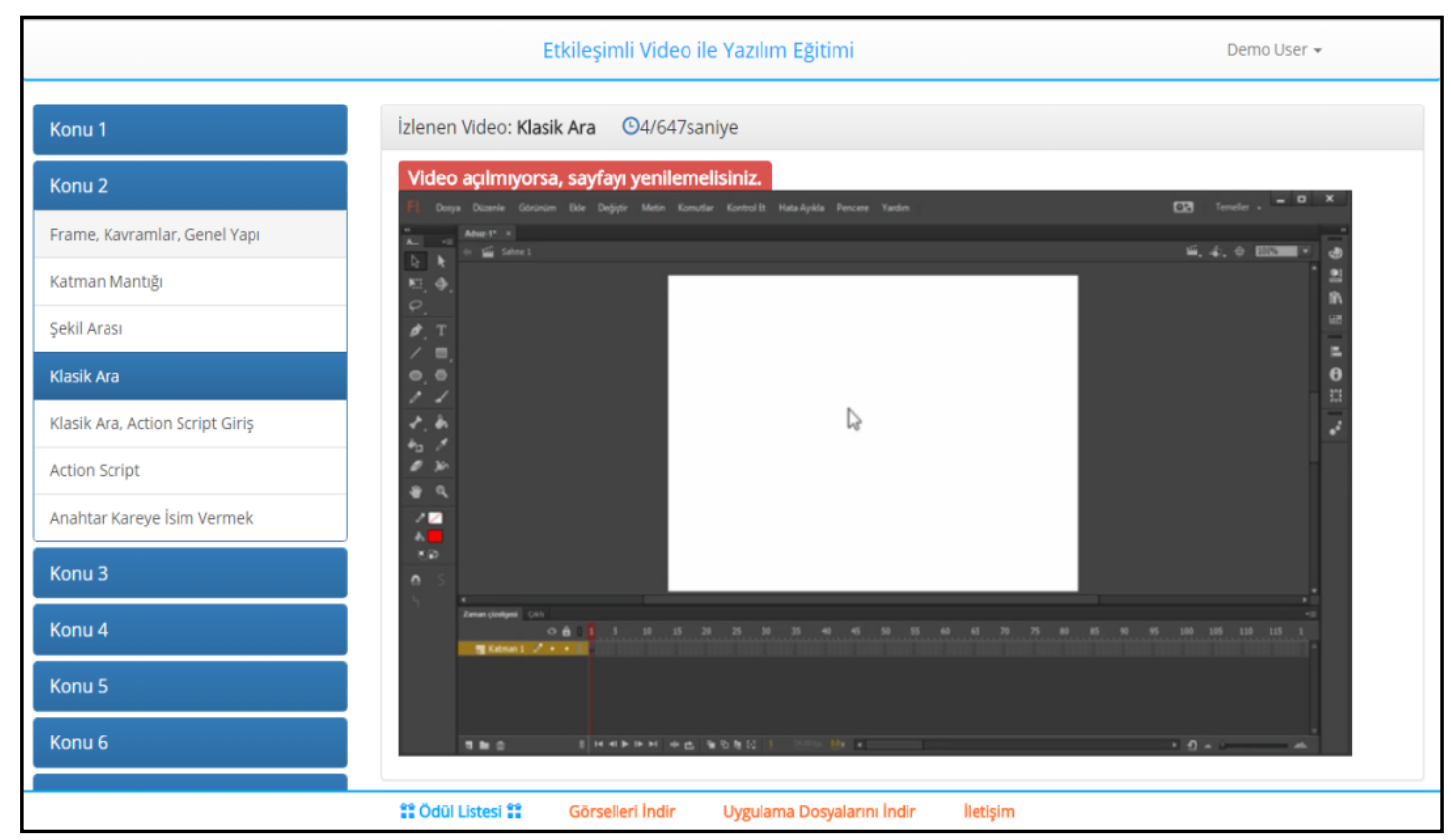

Figure 2. IVS Video Display Page

The student encounters the interaction added by the teacher while watching the video. Here, the student can respond or continue to follow without responding. The images used in the samples in the videos are downloaded through the screen, shown in the screenshot below, which is opened by clicking on the "download images" link. The application files of the samples developed in the videos can be downloaded from the "download application files" screen shown in the screenshot below. The views for the file download pages are presented in Figure 3. 


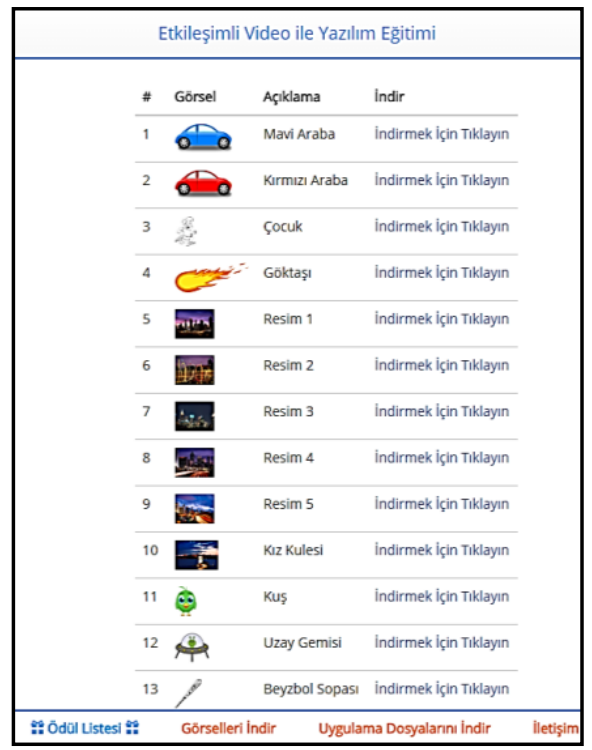

Downloading images used in samples

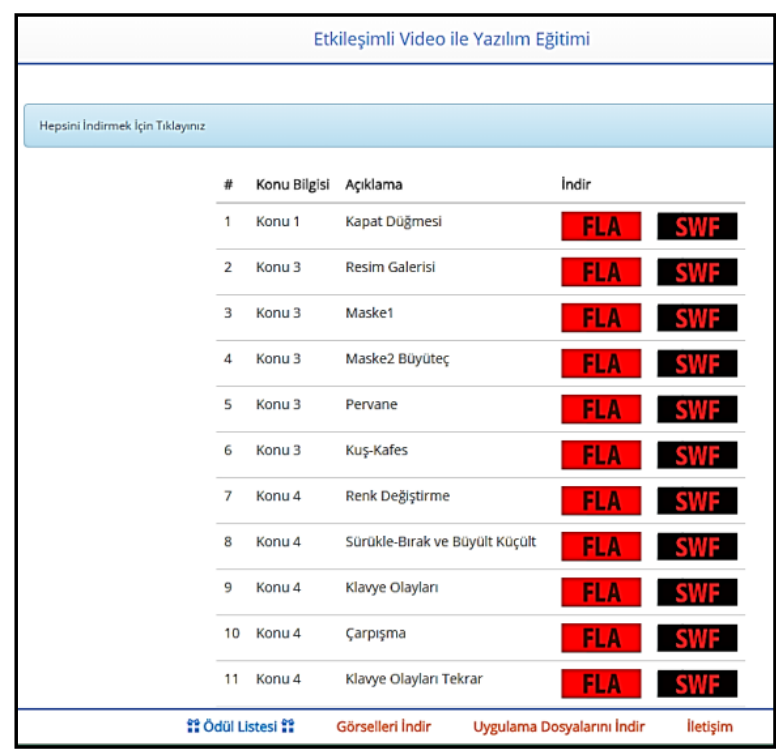

Downloading sample files

Figure 3. File download pages on IVS

The management panel of IVS is the administration section of the system. A view of the IVS management panel is presented in Figure 4.

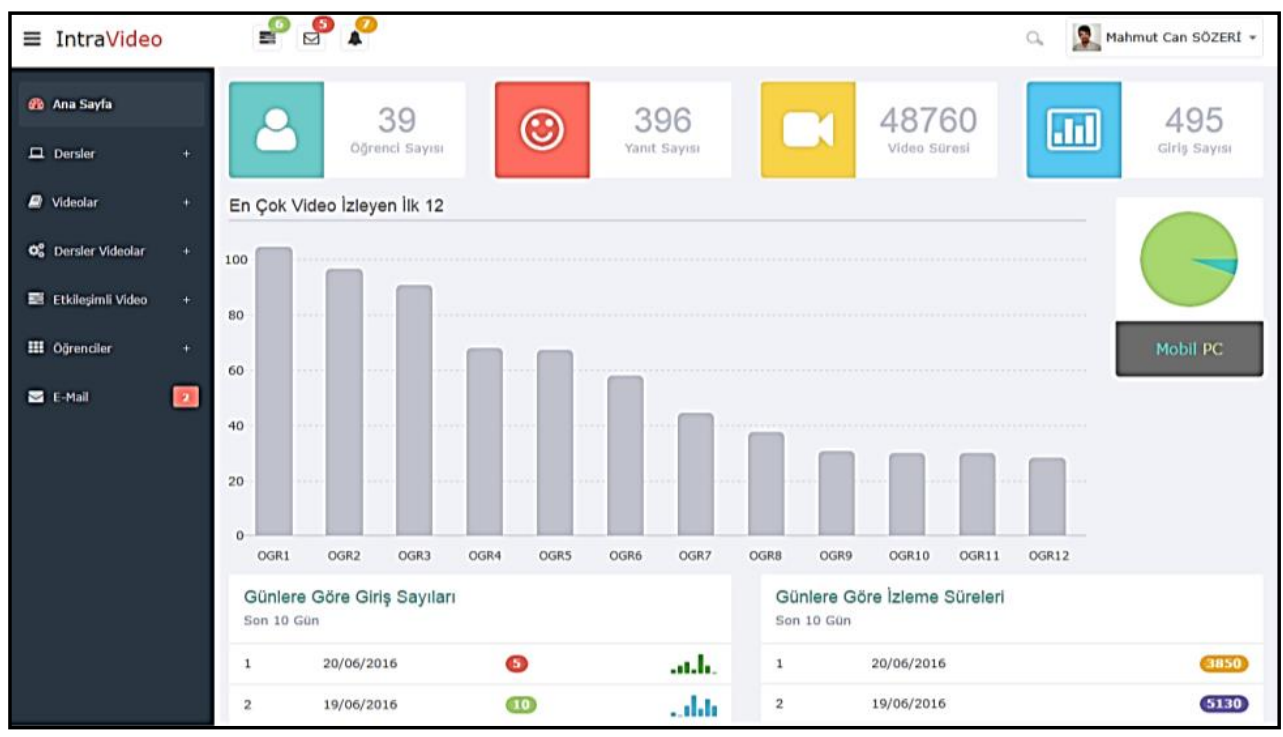

Figure 4. IVS Management Homepage

In this screen, the number of students currently using the application, answers to questions, total video time, number of entries, number of videos watched per student, number of students watching video per day, number of entries per day and number of entries per student are statistically shown. In addition to this, the administrator can do the following: changing students log in information; viewing, listing, adding, deleting, and updating courses; viewing, listing, adding, deleting, and updating videos; viewing, listing, adding, deleting, and updating interactions; viewing, listing, adding, and updating students; adding, deleting, and updating students. 


\subsection{Data Analysis}

The SPSS package program was used to analyze research data. When interpreting results, $p \leqslant .05$ as a level of significance accepted. Information about five students collected through interview form is presented in the study by correcting spelling errors. No coding or additional commentaries have been made. First of all, parametric and non-parametric controls were performed in the analysis of the data. A Single Factor Covariance Analysis (One Factor ANCOVA) was used to analyze whether the change in self-efficacy perception scores for programming differs significantly compared to interactive video monitoring rates. The Kruskal Wallis(KW) H-test was used to analyze whether interactive video monitoring rates differ according to students' learning style preferences. Correlation is used to interpret the amount and direction of the association between variables (Büyüköztürk, 2014). A correlation was used to examine the association between the amount of change in students' academic achievement and the amount of change in perceptions of self-efficacy regarding programming.

"In planning a study, researchers have the responsibility to evaluate carefully any ethical concerns." (Fraenkel, Wallen \& Hyun, 2011, p. 62). The whole process was carried out in compliance with the ethical standards of scientific research. First of all, it can be mentioned that the underlying reason for using causal-comparative design instead of an experimental one in the research was avoiding possible ethical issues. The authors wanted to deliver interactive videos to all students instead of only those in the experiential group. Any part of the process was not manipulated by the researchers. Watching the videos was not compulsory and entirely up to the students' decision. Additionally, the students did not see each other's follow-up times. The names of the students were not used in any part of the research. The consent of the participants was obtained for the user data of the research.

\section{Results}

In this section, the data obtained using the data collection tools, together with the results of the analysis of this data through the appropriate statistical methods and comments on these findings are included. When interpreting the findings, $\mathrm{p}<.05$ was considered as a level of significance.

\subsection{Self-efficacy perception}

Interactive video monitoring rates were obtained in hours/seconds by IVS. Twenty students who did not fill one or both of the self-efficacy scales for programming (CPSES) fill missing or write their name on the scales were excluded. The analysis was carried out with 40 student data $(\mathrm{N}=40)$ as shown in Table 5.

Table 5. Grouping of Interactive Video Monitoring Rates

\begin{tabular}{llll}
\hline Group No & Including Criteria & Condition & N \\
\hline Group 0 & Who Never Viewed The Interactive Video & Never viewed & 12 \\
Group 1 & Who Viewed The Interactive Video Infrequently & Who watches for 1.5 hours or less & 15 \\
Group 2 & Who Viewed The Interactive Video Actively & Who watches 1.6 hours or more & 13 \\
\hline
\end{tabular}

Since the group capacity is less than 50, the Shapiro-Wilks Test (Büyüköztürk, 2014) was used for normality analysis. According to the results, $\mathrm{p}$-values were greater than $\mathrm{a}=.05$ can be interpreted as the scores did not show a significant deviation from a normal distribution (Büyüköztürk, 2014). The normal distribution of data in the self-efficacy perception scale for programming has shown that parametric analysis methods can be used in data analysis (Büyüköztürk, 2014). A Single Factor Covariance Analysis (One Factor ANCOVA) was used to analyze whether there was a significant correlation between interactive video monitoring rates (independent variables) and CPSES final application scores (dependent variables). CPSES pre-application scores were used as a covariate. Explanations of the Covariance Analysis Results are shown in the table below. 
Table 6. CPSES Final Application Scores Covariance Analysis Results

\begin{tabular}{llllll}
\hline Source & Sum of Squares & Degree of Freedom & Mean of Squares & F & $\mathrm{p}$ \\
\hline CPSES Pre- Application & 2649.848 & 1 & 2649.848 & 75.838 & .000 \\
Group & 178.209 & 2 & 89.105 & 2.550 & .092 \\
Bug & 1257.879 & 36 & 34.941 & & \\
\hline
\end{tabular}

When table 6 was examined; It was inferred that CPSES scores did not differ significantly from the interactive video monitoring rates (groups), $(\mathrm{F}(2,36)=2.550 ; \mathrm{p}>.05)$. In other words, the perception of self-efficacy of programming has no relation to interactive video monitoring rates. Correlation between the amount of change in students' academic achievement and their perception of self-efficacy related to programming were analyzed using a simple correlation technique. Results are shown in Table 7.

Table 7. Results of Correlation Analysis Between the Growth of Academic Achievement and CPSES Scores of the Students.

\begin{tabular}{|c|c|c|c|}
\hline & & Pre-Post & CPSES Scores \\
\hline \multirow[t]{3}{*}{ Pre-Post Academic Success } & Pearson Correlation & & -.036 \\
\hline & Sig. (2-tailed) & & .841 \\
\hline & $\mathrm{N}$ & & 34 \\
\hline
\end{tabular}

In Table 7, it is seen that there is a negative and low-level significant relationship between the growth of academic achievement and CPSES scores of the participants $(\mathrm{r}=-0.036 ; \mathrm{p}<.05)$. Accordingly, it can be said that CPSES scores decrease when academic scores increase.

\subsection{Interactive Video Monitoring and Academic Achievement}

Interactive video monitoring rates were obtained in hours/seconds through IVS. In this context, the grouping is done as shown in Table 8. The study was carried out with 48 student data $(\mathrm{N}=48)$, as displayed in Table 8 , by subtracting 12 students who did not complete one or both of the academic achievement tests and missing ones and did not write their names.

Table 8. Distribution of Students Completing Academic Achievement Tests According to Interactive Video Monitoring Groups

\begin{tabular}{llll}
\hline & & Tag & N \\
\hline \multirow{3}{*}{ Group No } & 0 & Never viewed & 17 \\
& 1 & Viewed & 14 \\
& 2 & Actively Viewed & 17 \\
\hline
\end{tabular}

Since the number of students to be used in the analysis is less than 50, the Shapiro-Wilks test was used for normality analysis (Büyüköztürk, 2014). The normality distribution of achievement test data shows that parametric analysis methods can be used in data analysis. A Single Factor Covariance Analysis (One Factor ANCOVA) was used to analyze whether there was a significant correlation between interactive video monitoring rates (independent variable) and achievement test final application scores (dependent variable). Achievement test pre-application scores were used as the covariate. Explanations of the covariance analysis results are displayed in the table below. 
Table 9. Results of Covariance Analysis of Final Application Scores

\begin{tabular}{|c|c|c|c|c|c|}
\hline Source & Sum of Squares & Degree of Freedom & Mean of Squares & $\mathbf{F}$ & $\mathbf{p}$ \\
\hline $\begin{array}{l}\text { Achievement Test } \\
\text { Pre-Application }\end{array}$ & 44.289 & 1 & 44.289 & 5.184 & .028 \\
\hline Group & 35.596 & 2 & 17.798 & 2.083 & .137 \\
\hline Bug & 7099.000 & 44 & 34.941 & & \\
\hline
\end{tabular}

Table 9 shows that there was no significant difference in achievement scores compared to interactive video monitoring ratios (groups), $\mathrm{F}(2,44)=2.083, \mathrm{p}>.05$. In other words, academic success has no relation to interactive video viewing rates.

\subsection{Interactive Video Monitoring and Learning Styles}

In the second sub-problem of the study, it was investigated whether the learning style preferences differ significantly according to the interactive video monitoring rates. Learning style preferences were collected through the "Felder and Soloman Learning Styles Index." The results of this index show that each student has a learning style preference of 4 different factors and 2 different poles in each factor (Felder \& Silverman, 1988). Each pole has three different levels: strong, medium and weak (Felder \& Silverman, 1988).

The study was carried out with 46 students' data $(\mathrm{N}=46)$ by eliminating 14 students who did not fill out the learning styles index, fill out missing or write down their names. The non-parametric test, Kruskal Wallis(KW) H-test (Büyüköztürk, 2014), was used because the video monitoring rates did not show normal distribution. As shown in Table 10, According to the results of this study, interactive video monitoring rates (IVMR) did not differ according to learning style preferences ( $\mathrm{p}>.05$ ), in other words, it was found that learning style preferences do not have different effects on interactive video monitoring (viewing) rates.

Table 10. Comparison Learning Style Preferences with the IVMR "Kruskal Wallis" Tests

\begin{tabular}{llllll}
\hline Learning Style Factor & N & Mean Rank & sd & $x^{2}$ & p \\
\hline Think-strong and do- weak & 19 & 20.92 & 2 & 1.230 & .541 \\
Do-strong and think- weak & 14 & 25.39 & & & \\
Medium & 13 & 25.23 & & & \\
\hline Intuitive-strong and feeling-weak & 19 & 22.37 & 2 & .331 & .848 \\
Feeling-strong and intuitive- weak & 8 & 25.50 & & & \\
Medium & 19 & 23.79 & & & \\
\hline Auditory-strong and visual- weak & 10 & 26.40 & 2 & .708 & .702 \\
Visual-strong and auditory - weak & 17 & 23.41 & & & \\
Medium & 9 & 22.05 & & & \\
\hline Holistic - strong and sequential - weak & 14 & 26.36 & 2 & 1.284 & .526 \\
Sequential - strong and holistic - weak & 16 & 20.88 & & & \\
Medium & 16 & 23.63 & & & \\
\hline
\end{tabular}

It was observed that students with SEQUENTIAL - Strong and HOLISTIC - Weak) learning style preference had the lowest video-monitoring average (Mean Rank: 20.88). Additionally, AUDITORY-Strong and VISUALWeak learning style preference had the highest video-monitoring average (Mean Rank: 26.40). 


\section{Discussion and Conclusion}

In this study, the effects of interactive videos on students' academic achievement and self-efficacy perceptions on programming were investigated in the third-grade students of the Department of Computer Education and Instructional Technology. As the main result, it was found that interactive videos are not a significant variance in students' academic achievement and self-efficacy perceptions in programming education. Most of the studies in the literature, On the contrary of this research, has shown the positive effects of interactive video content on education (Duffy, 2008; Clothier, 2013; Altınpulluk, Kılınç, Mehmet \& Onur, 2020). The underlying causes of this finding can be explained with quotations from the literature. Ronchetti (2010) found that students thought that watching videos was tedious and burdensome. In this research, even in interactive content, students may have felt similar emotions. The size of videos can be another reason for the finding. Altinpulluk, etc. (2020), emphasized the segmentation and flexibility of video content and suggested to designers to divide the educational videos into "meaningful" parts to reach effective learning. If the case in the point is programming education, then the "meaningful" part is much more important, it can be suggested to researchers to think on this point meticulously. Similarly, Afify (2020), points out the length of interactive videos. He found that students watching short videos were more successful than others working with medium and long videos.

Secondly, it was found that students' learning style preferences did not have any impact on interactive video monitoring rates. In the literature, some of the studies support this finding. Guido and O'Connell(2015), investigated the link between learning style and online content usage in their studies. They found that the learning style of the individuals cannot be used as predictive data of online learning measures. Besides, Allert (2004) found no correlation between learning style and performance. As the result, it can be mentioned, even the content is programming language education, there is no relationship between learning styles and video monitoring rates of the students.

Additionally, the correlation between the variance in students' academic achievement and the variance in self-efficacy perception scores related to programming has been examined. It has been concluded that as academic achievement increases, the perception of self-efficacy about programming has decreased. This finding is opposite to the findings of Altun and Mazman (2012). Likewise, Tsai, Wang and Tsue (2019), have found a positive relationship between the programming experience and programming self-efficacy level of the students. Different results of the studies can be sourced from the characteristics of the research groups. The participants of this research were teacher candidates. Korkmaz and Altun (2014), has found that there was a significant difference between the programming self-efficacy perception scores of computer engineering and electrical-electronics engineering students. Therefore, it is believed that the change in the education process of students from different departments can be different.

In this research, the education of a script-based authoring tool was supported through interactive videos. The interaction of the videos was provided by using questions embedded in the video stream. For future research, the effects of different interaction technics in video-content to different programming courses can be investigated.

\section{References}

Afify, M. K. (2020). Effect of Interactive Video Length within E-Learning Environments On Cognitive Load, Cognitive Achievement and Retention of Learning. Turkish Online Journal of Distance Education, 21(4), 68-89.

Allert, J. (2004). Learning style and factors contributing to success in an introductory computer science course. Advanced Learning Technologies (s. 385-389). Joensuu, Finland: IEEE International Conference.

Akar, E. (2010). Yeni Eğitim Paradigması Olarak E-Öğrenme 2.0 ve Satış Elemanlarının Eğitiminde Kullanımı. Ç.Ü. Sosyal Bilimler Enstitüsü Dergisi, 19(1), s. 45-61.

Altınpulluk, H., Kılınç, H., Fırat, M., \& Yumurtacı, O. (2019). The influence of segmented and complete educational videos on the cognitive load, satisfaction, engagement, and academic achievement levels of learners. Journal of Computers in Education, 1-28.

Altun, A., \& Mazman, S. G. (2012). Programlamaya İlişkin Öz Yeterlilik Algısı Ölçeğinin Türkçe Formunun Geçerlilik ve Güvenirlik Çalışması. Eğitimde ve Psikolojide Ölçme ve Değerlendirme Dergisi, 3(2), s. 297-308. 
Arslan, B., \& Aksu, M. (2006). Orta Doğu Teknik Üniversitesi Mühendislik Öğrencilerinin Öğrenme Stili Profillerine Yönelik Betimsel Bir Çalışma. Eğitim ve Bilim, 31(141), s. 83-91.

Aşkar, P., \& Davenport, D. (2009). An Investigation of Factors Related to Self-Efficacy for Java Programming Among Engineering Students. The turkish Online Journal of Educational Technology, 8(1).

Barthel, R., Ainsworth, S., \& Sharples, M. (2013). Collaborative knowledge building with shared video representations. International Journal of Human-Computer Studies, 71(1), 59-75.

Brame, C. J. (2016). Effective Educational Videos. Retrieved from https://cft.vanderbilt.edu/guides-sub-pages/effective-educational-videos/

Bustamante, C. (2017). TPACK and teachers of Spanish: Development of a theorybased joint display in a mixed methods research case study. Journal of Mixed Methods Research, 13(2), 163-178.

Büyüköztürk, Ş. (2014). Sosyal Bilimler İçin Veri Analizi El Kitabı. Ankara: Pegem Akademi.

Büyüköztürk, Ş., Çakmak, E. K., Akgün, Ö., Karadeniz, Ş., \& Demirel, F. (2010). Bilimsel Araştırma Yöntemleri. Ankara: Pegem Akademi Yayıncılık.

Clothier, P. (2013). Interactive Video: the next big thing in mobile. Retrieved May, 4, 2020.

Duffy, P. (2008). Engaging the YouTube Google-Eyed Generation: Strategies for Using Web 2.0 in Teaching and Learning. The Electronic Jouyrnal of e-Learning, 6(2), s. 119-130.

Ersoy, H., Madran, R. O., \& Gülbahar, Y. (2011). Programlama Dilleri Öğretimine Bir Model Önerisi: Robot Programlama. Akademik Bilişim'11 - XIII. Akademik Bilişim Konferansı Bildirileri, (s. 731-736). Malatya.

Felder, R. M., \& Henriques, E. R. (1995). Learning and Teaching Styles In Foreign and Second Language Education. Foreign Language Annals, 28(1), s. 21-31.

Felder, R. M., \& Silverman, L. K. (1988). Learning and Teaching Styles in Engineering Education. Engineering Education, 78(7), s. 674-681.

Felder, R. M., \& Soloman, B. A. (1994). Index of Learning Styles (ILS). Retrieved from http://www4.ncsu.edu/unity/lockers/users/f/felder/public/ILSpage.html

Fraenkel, J., Wallen, N., \& Hyun, H. (2011). How to Design and Evaluate Research in Education (8th b.). New York: McGraw-Hill Education.

Gözüm, S., \& Aksayan, S. (1999). Öz-Etkililik-Yeterlik Ölçeği'nin Türkçe Formunun Güvenirliik ve Geçerliliği. Atatürk Üniv. Hemşirelik Yüksekokul Dergisi, 2(1), s. 21-34.

Howard, R. A., Carver, C. A., \& Lane, W. D. (1996). Felder's Learning Styles, Bloom's Taxonomy, and The Kolb Learning Cycle: Tying It All Together In The CS2 Course. SIGCSE '96 Proceedings of the twenty-seventh SIGCSE technical symposium on Computer science education, 28, s. 227-231. New York, NY, USA.

Hrastinski, S., \& Monstad, T. (2014). Exploring the relationship between the use of an interactive video website and organizational learning. New Media \& Society, 16(4), 594-614.

Kalelioğlu, F. (2015). A new way of teaching programming skills to K-12 students: Code.org. Computers in Human Behavior, s. 200-210.

Karaman, S., Yıldııı, S., \& Kaban, A. (2008). Öğrenme 2.0 Yaygınlaşıyor: Web 2.0 Uygulamalarının Eğitimde Kullanımına İlişkin Araştırmalar ve Sonuçları. XIII. Türkiye'de İnternet Konferansı Bildirileri, (s. 35-40). Ankara.

Kolowich, L. (2016). 31 Video Marketing Statistics to Inform Your Strategy Retrieved from http://blog.hubspot.com/marketing/video-marketing-statistics\#sm. 000qy2oh4113adblqf82 ndjr4muir

Korkmaz, Ö., \& Altun, H. (2014). Adapting Computer Programming Self-Efficacy Scale and Engineering Students' Self-Efficacy Perceptions. Online Submission, 1(1), 20-31.

Kozma, R. B. (1986). Implications of instructional psychology for the design of educational television. Educational Technology Research \& Development, 34(1), s. 11-19.

Kukul, V., \& Gökçearslan, Ş. (2014). Scratch ile Programlama Eğitimi Alan Öğrencilerin Problem Çözme Becerilerinin İncelenmesi. 8th International Computer \& Instructional Technologies Symposium, (s. 58-63). Edirne. 
Litzinger, T. A., Lee, S. H., Wise, J. C., \& Felder, R. M. (2005). A study of the reliability and validity of the Felder-Soloman Index of Learning Styles. Proceedings of the 2005 American Society for Education Annual Conference \& Exposition, (s. 1-16).

Meij, H. v., \& Meij, J. v. (2014). A comparison of paper-based and video tutorials for software learning. Computers \& Education, 78, s. 150-159.

Munoz, C. L., \& Towner, T. L. (2009). Opening Facebook: How to Use Facebook in the College Classroom. Proceedings of society for information technology \& teacher education international conference. South Carolina.

Petan, A. S., Petan, L., \& Vasiu, R. (2014). Interactive Video in Knowledge Management: Implications for Organizational Leadership. Challenges and Innovations in Management and Leadership - 12th International Symposium in Management, 124, s. 478-485.

Ramalingam, V., \& Wiedenbeck, S. (1998). Development and Validation of Scores on a Computer Programming Self-Efficacy Scale and Group Analyses of Novice Programmer Self-Efficacy. Journal of Educational Computing Research, 19(4), s. 367-381.

Ronchetti, M. (2010). Using Video Lectures to Make Teaching More. International Journal of Emerging Technologies in Learning (iJET), 5(2), 45-48.

Samancı, N. K., \& Keskin, Ö. M. (2007). Felder ve Soloman Öğrenme Stili İndeksi: Türkçeye Uyarlanması ve Geçerlik-Güvenirlik Çalışması. Ahi Evran Üniversitesi Kırşehir Eğitim Fakültesi Dergisi, 8(2), s. 37-54.

Schaffer, L. C., \& Hannafin, M. J. (1986). The effects of progressive interactivity on learning from interactive video. ECTJ, 34(2), s. 89-96.

Seferoğlu, S., \& Akbıyık, C. (2005). İlköğretim Öğretmenlerinin Bilgisayara Yönelik Öz-Yeterlik Algıları Üzerine Bir Çalışma. Eğitim Araştırmaları-Eurasian Journal of Educational Research, 19, s. 89-101.

Sönmez, V., \& Alacapınar, F. G. (2013). Örneklendirilmiş Bilimsel Araştırma Yöntemleri. Ankara: Anı Yayincilik.

Thomas, L., Ratcliffe, M., Woodbury, J., \& Jarman, E. (2002). Learning styles and performance in the introductory programming sequence. SIGCSE '02 Proceedings of the 33rd SIGCSE technical symposium on Computer science education, 34, s. 33-37. New York, NY, USA.

Tsai, M. J., Wang, C. Y., \& Hsu, P. F. (2019). Developing the computer programming self-efficacy scale for computer literacy education. Journal of Educational Computing Research, 56(8), 1345-1360.

Tu, C., Blocher, M., \& Ntoruru, J. (2008). Integrate Web 2.0 technology to facilitate online professional community: EMI special editing experiences. Educational Media International, 45(4), 335-341.

Yıldırım, N., \& Özmen, B. (2012). Video Paylaşım Sitelerinin Eğitsel Amaçlı Kullanımı. e-Journal of New World Sciences Academy, 7(1).

Yin, Z.-X., Lin, C.-H., Yang, C.-T., \& Chen, Z.-Z. (2013). An interactive-video system to medical e-learning. Orange Technologies (ICOT), (s. 321-324). Tainan.

Zhang, D., Zhou, L., Briggs, R. O., \& Nunamaker Jr., J. F. (2006). Instructional video in e-learning: Assessing the impact of interactive video on learning effectiveness. Information \& Management, 43(1), s. 15-27. 